\title{
Detection and estimation of human papillomavirus viral load in patients with cervical lesions
}

\author{
Rahman $\mathrm{T}^{1}$, Tabassum $\mathrm{S}^{2}$, Jahan $\mathrm{M}^{2}$, Nessa $\mathrm{A}^{2}$, Ashrafunnessa ${ }^{3}$ \\ ${ }^{I}$ Department of Microbiology, Dhaka Community Medical College Hospital, Dhaka, ${ }^{2}$ Department of Virology, \\ Bangabandhu Sheikh Mujib Medical University, Dhaka, ${ }^{3}$ Department of Obstetrics \& Gynaecology, \\ Bangabandhu Sheikh Mujib Medical University, Dhaka,Email: tanjila_lo@yahoo.com
}

\begin{abstract}
Human papillomavirus (HPV) high risk genotype infection and HPV viral load influences the development of invasive cervical cancer and cervical intra-epithelial neoplasia (CIN). HPV DNA testing for screening of cervical cancers may play a potential role in its early detection and management. The present study detected HPV DNA and estimated HPV viral load in different types of cervical lesions among Bangladeshi women. Using the Hybrid Capture 2 (HC2) assay, HPV DNA was tested among 68 women between 25-70 years of age. A total of $13(19.1 \%)$ cases were positive for HPV DNA. The highest viral load $\left(501 \times 10^{3}\right.$ copies $\left./ \mathrm{ml}\right)$ was detected in a patient with invasive carcinoma, while the lowest viral load $\left(105 \times 10^{3}\right.$ copies $\left./ \mathrm{ml}\right)$ was detected from a case of chronic cervicitis. The mean viral load in CIN I was $119.25 \times 10^{3} \pm 12.5 \times 10^{3}$ copies $/ \mathrm{ml}$ (range: $110 \times 10^{3}-137$ $\mathrm{x} 10^{3}$ ) and $208.50 \times 10^{3} \pm 0.59 \times 10^{3}$ copies/ml (range: $139 \times 10^{3}-305 \times 10^{3}$ ) in CIN II / III. Interestingly, HPV DNA was detected from a patient with normal cytological findings. Our study observed a moderate presence of high-risk HPV genotypes among women with cervical lesions. The HPV viral load varied with the age of the patients and stage of cervical lesions. The HC2 assay is a promising tool for diagnosing high-risk HPV infection especially before cytology tests show any abnormality.
\end{abstract}

\section{Introduction}

Worldwide, cervical carcinoma ranks second among the common cancers in women, with an estimated 4,70,600 new cases and 2,33,400 deaths per year ${ }^{\mathbf{1 - 2}}$. Cervical cancer primarily occur in developing countries where women have limited or no access to effective disease prevention services. Among the Asian countries, India, Bangladesh, Nepal and Sri Lanka together contribute to around one-third of the global cervical cancer burden ${ }^{3}$. In South Asia, Bangladesh and India have an annual incidence of 11,956 and 1,25,952 respectively ${ }^{4}$.

The human papillomavirus (HPV), an oncogenic DNA virus and a member of the papovoviridae family is the main cause of most cervical cancers and cervical intraepithelial neoplasias (CIN) worldwide $^{1}$. The virus is predominantly sexually transmitted and is a high-risk factor for development of cervical carcinoma ${ }^{5-7}$. The prevalence of human papillomavirus infection varies from 7 - 14\% among the general population in India, Bangladesh, Nepal and Sri Lanka ${ }^{8}$. Persistent infection with certain genotypes of carcinogenic HPV causes most cases of cervical cancers 9 . Among 130 genotypes of HPV, types 16, $18,31,33,35,39,45,51,52,56,58,59$ and 68 are "high risk" HPVs. Globally, HPV 16 and 18 contribute to over $70 \%$ of all cervical cancers while HPV types 31, 33, 35, 45, 52 and 58 are responsible for an additional $20 \%$ of $\operatorname{cases}^{\mathbf{1 0}}$. The effect of high-risk types of HPV infection on CIN development is greatly influenced by the number of viral copies, as higher loads are more strongly associated with severe disease. Various studies suggest that a high HPV-DNA viral load may be a potential marker for identifying women at greater risk of CIN progression, while some indicate that high viral load in cytological normal epithelium may also be a risk factor for neoplastic $\operatorname{progression}^{11-13}$.

As cervical cancer generally develops slowly from precursor lesions, regular screening for high risk HPV types should be performed to identify lesions with potential for progression to invasive cancers ${ }^{14}$. At present, molecular detection of HPV DNA is the gold standard for identification of HPV, and is being evaluated as a prospective alternative or adjunctive to cervical cytology for the early detection of cervical cancer precursors and prevention of invasive cervical cancer ${ }^{15}$. Information on HPV type-specific prevalence or viral load in women with or without cervical lesions is very limited from Bangladesh. Therefore, the present study detected HPV DNA and estimated 
the viral load by the Hybrid capture 2 assay to determine the efficacy of this test among patients with different grades of cervical diseases.

\section{Materials and Methods}

The study was conducted among 68 women with different types of cervical lesions from January to December, 2008. Patients were selected from the Obstetrics and Gynecology Out-Patients Department (OPD) of Bangabandhu Sheikh Mujib Medical University (BSMMU) Hospital, Dhaka. Conventional methods are used for diagnosis of cervical lesion of the patients included Visible Inspection of Acetic acid (VIA), colposcopy, histopathology and pap smear tests. Sexually active women above 25 years of age having history of post-coital bleeding, per-vaginal spotting and /or spontaneous bleeding, patients referred for colposcopy due to abnormalities detected on previous pap's smears, VIA test and histopathological examinations, clinically unhealthy looking cervix on per-vaginal examination, patients with low-grade squamous intra-epithelial lesions (LSIL) included in this study.

After taking informed written consent, cervical specimen for HPV DNA was collected in a cervical sampler consisting of a cervical brush and specimen transport medium (STM), supplied by the manufacturer of HC2 (Digene Corporation, USA). Detection of HPV and estimation of viral load was carried out at the Department of Virology, BSMMU.

At the Molecular Virology Laboratory of the Dept. of Virology BSMMU, specimens were stored at $20^{\circ} \mathrm{C}$ until tested. Determination of HPV and estimation of viral load was done by the hybrid capture 2 (HC2) high-risk HPV DNA test kit (Digene Corporation, Gaithersburg, MD 20878, USA; catalog no-21293) according to the manufacturer's instructions. It detected 13 high-risk HPV types ie, 16, 18, 31, 33, 35, 45, 52, 56, 58, 59 and 68. Briefly, specimens were treated with sodium hydroxide to release and denature the DNA from cervical cells and hybridized to RNA probes designed for high-risk HPV types. The DNA-RNA hybrids that formed were captured onto the surface of microtiter wells using antibodies specifically designed for hybrid molecules. Then, alkaline phosphatase was added. Unreacted material was removed by washing, and chemiluminescent substrate (dioxetane) was added as a substrate. The fluorescent activity was measured using a luminometer and result of the test was expressed as relative light unit (RLU). A positive result from the
HC2 test is defined as a net fluorescent activity that is greater than or equal to the fluorescent activity average of three manufacture positive controls. HC2 high-risk HPV DNA cut-off was $1.0 \mathrm{pg} / \mathrm{mL}$, which is equivalent to $1,00,000$ copies of HPV DNA.

VIA test and Colposcopy examination were done in the VIA and Colposcopy Center of BSMMU. Cytological and histopathological investigations were conducted at the Department of Pathology, BSMMU by conventional methods.

Statistical analysis:

Data obtained from the study were entered and analyzed by computer-based software SPSS Version 12. Test of significance was estimated by using $\mathrm{Z}$ test. Probability less than 0.05 were considered as significant.

\section{Results}

Cervical samples from a total of 68 women were tested for HPV DNA by the HC2 assay. The age of the study population ranged from 25-70 (mean 41.4 \pm 10.6 ) years. HPV DNA was detected from 13 (19.1\%) samples. The prevalence of HPV infection increased with increasing age, with twice the prevalence among older than younger age groups. The maximum number of HPV DNA $(26.7 \%)$ were detected in the $>40$ years age group. In the $25-40$ years age group, HPV DNA was detected from 5 $(13.2 \%)$ samples (Table-I). No statistically significant age difference was observed among the age groups $(\mathrm{p}=0.080)$.

HPV viral load ranged from $105 \times 10^{3}$ to $501 \times 10^{3}$ copies $/ \mathrm{ml}$ among the study population. The highest viral load $\left(501 \times 10^{3}\right.$ copies $\left./ \mathrm{ml}\right)$ was detected in one invasive carcinoma patient, while the lowest viral load $\left(105 \times 10^{3}\right.$ copies $\left./ \mathrm{ml}\right)$ was detected in a case of chronic cervicitis. The mean viral load was $119.25 \times 10^{3} \pm 12.5 \times 10^{3}$ copies $/ \mathrm{ml}$ (range: $110 \times$ $\left.10^{3}-137 \times 10^{3}\right)$ in CIN I while this was $208.50 \times$ $10^{3} \pm 0.59 \times 10^{3}$ copies/ml (range: $139 \times 10^{3}-305 \times$ $10^{3}$ ) for CIN II/ III. HPV DNA was detected from a patient with normal cytology with a viral load of $133 \times 10^{3}$ copies /ml (Table-II).

Table I: Rate of detection of HPV DNA among different age groups of study population.

\begin{tabular}{lccc}
\hline $\begin{array}{c}\text { Age } \\
\text { (in years) }\end{array}$ & $\begin{array}{c}\text { Total no. of cases } \\
(\mathrm{n}=68)\end{array}$ & $\begin{array}{c}\text { HPV DNA } \\
\text { positive }\end{array}$ & p value \\
\hline $25-40$ & 38 & 5 & \\
& & $(13.2)$ & \\
$>40$ & 30 & $\begin{array}{c}5 \\
(26.7)\end{array}$ & 0.080 \\
\hline Total & 68 & 13 & \\
& & $(19.1)$ & \\
\hline
\end{tabular}

Note: i) z test was done to measure the level of significance. ii) Figures within parenthesis indicate percentage. 
Table II: HPV viral load in different types of cervical lesions.

\begin{tabular}{|c|c|c|c|c|}
\hline $\begin{array}{l}\text { Status of } \\
\text { Cases }\end{array}$ & $\begin{array}{c}\text { No. of cases } \\
(n=12\end{array}$ & $\begin{array}{l}\text { Viral load } \\
(\text { copies/ml) }\end{array}$ & $\begin{array}{l}\text { Mean Viral load } \\
\text { Copies/ml. } \pm \text { SD }\end{array}$ & Range \\
\hline Chronic & 1 & $105 \times 10^{3}$ & & \\
\hline \multicolumn{5}{|l|}{ Cervicitis } \\
\hline CINI & 4 & $\begin{array}{l}137 \times 10^{3} \\
119 \times 10^{3} \\
110 \times 10^{3} \\
111 \times 10^{3}\end{array}$ & $\begin{array}{l}119.25 \times 10^{3} \\
\pm 12.5 \times 10^{3}\end{array}$ & $\begin{array}{l}110 \times 10^{3}- \\
137 \times 10^{3}\end{array}$ \\
\hline CINII/III & 6 & $\begin{array}{c}139 \times 10^{3} \\
171 \times 10^{3}\end{array}$ & $\begin{array}{c}208.50 \times 10 \pm \\
0.59 \times 10^{3}\end{array}$ & $\begin{array}{l}139 \times 10^{3}- \\
305 \times 10^{3}\end{array}$ \\
\hline & & $\begin{array}{l}201 \times 10^{3} \\
305 \times 10^{3} \\
188 \times 10^{3} \\
247 \times 10^{3}\end{array}$ & & \\
\hline $\begin{array}{c}\text { Invasive } \\
\text { carcinoma }\end{array}$ & 1 & $501 \times 10^{3}$ & & \\
\hline $\begin{array}{c}\text { Normal } \\
\text { Cytology }\end{array}$ & 1 & $133 \times 10^{3}$ & & \\
\hline
\end{tabular}

Note:i) $\mathrm{HC} 2$ high-risk HPV DNA test cutoff $1 \mathrm{pg} / \mathrm{ml}$ is equivalent to $100000 \mathrm{HPV}$ copies/ $\mathrm{ml}$. RLU/ cut off value ratios $\geq 1.0$ was considered as "Positive".

ii) Viral load in HPV positive cases were considered only

iii) No abnormal cytology was found in one patient with positive HPV DNA test.

\section{Discussion}

Human papilloma virus (HPV) is considered as the main cause of most cervical cancers and cervical intraepithelial neoplasia (CIN), and is thus an important public health challenge for the prevention of cervical carcinoma ${ }^{\mathbf{1 6 - 1 7}}$. Traditional cytology using Papanicolaou (Pap) smear has played a major role in reducing mortality from cervical cancer. However, high rates of false negative results remains a major limitation of traditional cytological screening ${ }^{18}$. The HPV DNA testing has opened the door for an alternative surveillance mechanism to routine cytological screening. In this study, we detected HPV DNA from $13(19.1 \%)$ ) patients with various grades of cervical lesions. The overall and age-specific prevalence of HPV among women appears to vary by countries, region within countries and population subgroups. In Latin America, the frequency range was between $15 \%$ and $16 \%$ in Mexico, Costa Rica and Colombia ${ }^{\text {19-21 }}$. Large studies have found 16.7 per cent of all screened women to be HPV DNA positive ${ }^{22}$. These geographical variations may be due to the prevalence of different subtypes of HPV and host related factors ${ }^{23}$. Moreover, demographic, cultural, socioeconomic variables, multiparity, long term contraceptive use, young age at first coitus, multiple sexual partners, low socioeconomic status, low education level, poor genital hygiene, cigarette smoking, genital tract infections etc, are probable co-factors that increase the risk of cervical cancer in women with HPV infection ${ }^{24-25}$.
An important finding of our study was the agerelated distribution of HPV lesions. While the prevalence of HPV was $13.2 \%$ among the $25-40$ years age group, this increased two-fold to $26.7 \%$ among the above 40 years age group. Almost similar results have been reported from Venezuela where $27 \%$ of HPV infection was detected in women between 45 to 54 years and $20 \%$ in women below 25 years $^{26}$. Age-specific prevalence estimates show that HPV infection in women is predominantly acquired in adolescence, but peak prevalence in middle-aged women differ widely across geographical regions mainly due to differences in sexual behavior. However, HPV prevalence remains fairly constant across all age groups in high-prevalence countries of Asia and Africa $^{27}$. Most studies observe that HPV infection usually reaches a peak of $20 \%$ among women between 20 to 24 years of age, with a subsequent decline to approximately $3 \%$ among women over 30 years ${ }^{28-29}$. Despite a decline in HPV prevalence above the age of 25 years, the risk for cervical cancer increases until women reach their fifties, probably due to risks associated with persistent HPV infection. Women over 30 years of age who are infected with high-risk HPV may be up to 116 times more likely to develop severe dysplasia than uninfected women ${ }^{28}$. Other factors regarding the progression of HPV infection to cervical cancer is related to a woman's immune status. Women with compromised immune system due to malnutrition, pregnancy, immunosuppressive chemotherapy, or co-infection with the human immunodeficiency virus (HIV) are at increased risk of progression ${ }^{30-31}$.

In this study, a distinct upward trend of high-risk HPV DNA viral load was found to correlate with the histologic grade of the lesion, being highest for invasive carcinoma followed by CIN I, CIN II/II and lowest for chronic cervicitis . Here the highest viral load (501 x $10^{3}$ copies $\left./ \mathrm{ml}\right)$ was detected in a patient with invasive carcinoma, while the lowest viral load $\left(105 \times 10^{3}\right.$ copies $\left./ \mathrm{ml}\right)$ was detected from a case of chronic cervicitis. The mean viral load in CIN I was $119.25 \times 10^{3} \pm 12.5 \times 10^{3}$ copies $/ \mathrm{ml}$ (range: $110 \times 10^{3}-137 \times 10^{3}$ ) and $208.50 \times 10^{3} \pm$ $0.59 \times 10^{3}$ copies $/ \mathrm{ml}$ (range: $139 \times 10^{3}-305 \times 10^{3}$ ) in CIN II / III (Table-II). Sun et al. described Women who had a high viral load, according to the hc2 test, were found to be at significantly greater risk squamous intraepithelial lesion (SIL) and cervical carcinoma ${ }^{\mathbf{1 3}}$. Various researchers have speculated that there may be a relationship between high-risk HPV DNA viral load with persistent infection and the subsequent development of high squamous intraepithelial lesion (HSIL) and invasive cervical carcinoma ${ }^{32}$. Some studies have 
also shown that the amount of HPV DNA is a useful predictor of progression to cervical carcinoma, and concluded that the risk of cancer increased correspondingly ${ }^{33}$. We found the quantative information provided by the hybrid capture II assay to be quite accurate, reliable and reproducible. Thus, the quantification of viral load of high-risk HPV types may be a useful tool for patients with suspicious cervical lesions. An interesting case in our study was the detection of high-risk HPV DNA from a patient with no signs of any cervical lesion. The significance of the relatively high copy number of HPV DNA in the sample with normal cytological findings could not be addressed in this cross-sectional study. HPV DNA is presumed to be associated with latently infected cells, however, sampling errors may also be considered. Prospective studies of cytologically normal women using a quantitative analysis of HPV DNA may help to determine the natural history and biology of latent infections. However, there have also been conflicting reports about correlation between viral load and risk of $\mathrm{SIL}^{\mathbf{3 4}}$. Thus, the quantitative aspects of HPV viral load testing merits further evaluation in order to establish its potential for cancer prevention in risk groups.

Sample size of this study is small due to its high cost and lack of awareness of HPV infection in suspected cervical carcinoma patients. However, further extensive studies with larger sample size should be carried out for use of this test for screening purpose. The main limitation of the HPV test is its high cost, which limits its use in routine cervical mass screening in resource limited settings. Nevertheless, it has been shown to be a useful tool when combined with cytology, diagnosing highrisk infections in apparently normal tissues, which may ultimately help reduce the risk of cervical cancer.

\section{References}

1. Munoz N. Human papillomavirus and cancer: the epidemiological evidence. J Clin Virol 2000; 19: 1-5.

2. Parkin DM, Bray FI, Devessa SS. Cancer Burden in the year 2000. The global Picture. Eur J Cancer 2001; 37 (Suppl 8): s4-s66.

3. Ferlay J, Shin HR, Bray F, Forman D, Mathers C, Parkin DM. GLOBOCAN 2008, cancer incidence and mortality worldwide: IARC CancerBase number 10 . Lyon, France: International Agency for Research on Cancer; 2010. http://globocan.iarc.fr (accessed Sept 1, 2012).

4. Ferlay J, Shin HR, Bray F, Forman D, Mathers C, Parkin DM. Estimates of worldwide burden of cancer in 2008: GLOBOCAN 2008. Int $J$ Cancer 2010; 127(12): 2893-2917.

5. Lorincz, AT, Reid R. Association of Human papilloma virus with gynecologic cancer. Curr Opi Oncology1989; 1:123-132.

6. Koutsky LA, Holmes KK, Critchlow CW, Stevens CE, Paavonen J, Beckmann AM, et al. A cohort study of the risk of cervical intraepithelial neoplasia grade 2 or grade 3 in relation to papillomavirus infection. $N$ Engl J Med 1992; 327:1272.

7. Schiffman MH, Bauer HM, Hoover RN, Glass AG, Cadell DM, Rush BB, et al. Epidemiologic evidence showing that human papillomavirus infection causes most cervical intraepithelial neoplasia. J Natl Cancer Inst 1993; 85(12):958-964.

8. Sankarnarayananan R, Bhatla N, Gravitt PE, Basu P, Esmy PO, Ashrafunnessa KS, et al. Human papillomavirus infection and cervical cancer prevention in India, Bangladesh, Sri Lanka and Nepal. Vaccine 2008; 26S: M43-M52.

9. Walboomers JM, Jacobs MV, Manos MM, Bosch FX, Kummer JA, Shah KV, et al. Human papillomavirus is a necessary cause of invasive cervical cancer worldwide. J Pathol 1999; 189: 12-19.

10. Munoz N, Bosch FX, Castellsague X, Diaz M, Sanjose $\mathrm{S}$, Hamouda $\mathrm{D}$, et al. Against which human papillomavirus types shall we vaccinate and screen? The International perspective. Int J Cancer 2004; 111:278-285.

11. Josefsson AM, Magnusson PK, Ylitalo N, Sorensen P, Qwarforth-Tubbin P, Andersen PK, et al. Viral load of human papilloma virus 16 as a determinant for development of cervical carcinoma in situ: a nested case-control study. Lancet 355: 2000; 2189-2193.

12. van Duin $M$, Snijders PJ, Schrijnemakers HF, Voorhorst FJ, Rozendaal L, Nobbenhuis MA, et al. Human papillomavirus 16 load in normal and abnormal cervical scrapes: an indicator of CIN II/III and viral clearance. Int J Cancer 2002; 98: 590-595.

13. Sun CA, Liu JF, Wu DM, Nieh S, Yu CP, Chu TY. Viral load of high-risk human papillomavirus in cervical squamous intraepithelial lesions. Int J Gynecol Obstet 2002; 76: 41-47.

14. Saslow D, Runowicz CD, Solomon D, Moscicki A-B, Smith RA, Eyre HJ, Cohen C. American Cancer Society Guideline for early detection of cervical neoplasia and cancer. CA Cancer J Clin 2002; 52: 342362.

15. Cuzick J. Human papillomavirus testing for primary cervical cancer screening. JAMA 2000; 283: 108-109.

16. Munoz N, Bosch FX, de Sanjose S, Herrero R, Casellsague $\mathrm{X}$, Shah KV, et al. Epidemiologic classification of human papillomavirus types associated with cervical cancer. $N$ Eng J Med 2003; 348: 518-527.

17. Skerlev M, Giri M, Skerlev HS. Human Papillomavirus male genital infections: Clinical variations and the 
significance of DNA typing. Clinics Dermatol 2002; 20: $173-178$.

18. Morrison H. Human papillomavirus absence predicts normal cervical histopathologic findings with abnormal papanicolaou smears. J Hum Virol 1993;4: 283-7.

19. Lazcano E, Herrero R, Muñoz N, Cruz A, Shah K, Alonso $\mathrm{P}$, et al. Epidemiology of HPV infection among Mexican women with normal cervical cytology. Int $J$ Cancer 2001; 91: 412-420.

20. Herrero R, Hildesheim A, Bratty C, Sherman M, Hutchinson M, Morales J, et al. Population-based study of human papillomavirus infection and cervical neoplasia in rural Costa Rica. J Natl Cancer Inst (Bethesda) 2000; 92: 464-474.

21. Molano M, Posso H, Weiderpass E, van der Brule AJ, Ronderos M, Franceschi S, et al. Prevalence and determinants of HPV infection among Colombian women with normal cytology. Br J Cancer 2002; 87 (3): 324-333.

22. Clavel C, Masure M, Bory JP, Putaud I., Mangeonjean C, Lorenzato M, et al. Hybrid Capture II-based human papillomavirus detection, a sensitive test to detect in routine high-grade cervical lesions: a preliminary study on 1518 women. Br J Cancer1999; 80(9): 1306-1309.

23. Bosch FX, Manos MM, Muñoz N, Sherman M, JansenAM, Peto J, et al. Prevalence of human papillomavirus in cervical cancer: a worldwide perspective. J Natl Cancer Inst 1995; 87:796-802.

24. Muñoz N, Franceschi S, Bosetti C, Moreno V, Herrero $\mathrm{R}$, Smith IS, et al. Role of parity and human papillomavirus in cervical cancer: The IARC multicentric case-control study. Lancet 2002; 359:1093-1101.

25. Moreno V, Bosch FX, Muñoz N, Meijer CJ, Shah KV, Walboomers IM, et al. Effect of oral contraceptives on risk of cervical cancer in women with human papillomavirus infection: The IARC multicentric casecontrol study. Lancet 2002; 359:1085-1092.
26. Contreras-Irrazabal L, Correnti M, Ávila M, Guerrero A, León A. Virus Papiloma Humano (VPH) en contexto ecológico ve nezolano (I): Diagnóstico citológico y molecular. Salus 2008, 12, 3:30-44.

27. Smith JS, Melendy A, Rana RK, Pimenta JM. Agespecific prevalence of infection with human papillomavirus in females: a global review. $J$ Ado Health 2008; 43: S5-S25.

28. Meijer CJ, Helmerhorst TJ, Rozendaal L, van der Linden JC, Voorhorst FJ, Walboomers JM. HPV typing and testing in gynaecological pathology: has the time come? Histopathol 1998; 33: 83-86.

29. Sellors JW, Mahoney JB, Kaczorowski J, Lytwyn A, Bangura $\mathrm{H}$, Chong S, et al. Prevalence and predictors of human papillomavirus infection in women in Ontario, Canada. Can Med Assoc J 2000;163(5): 503508 .

30. Sedlacek TV. Advances in the diagnosis and treatment of human papillomavirus infections. Clin Obstet Gynecol 1999; 42(2): 206-220.

31. Temmerman M, Tyndall MW, Kidula N, Claeys P, Muchiri L, Quint W. Risk factors for human papillomavirus and cervical precancerous lesions, and the role of concurrent HIV-1 infection. Int J Gynaecol Obstet 1999; 65: 171-181.

32. Hubbard RA. Human Papillomavirus Testing Methods II. CAP Strategic Science II (HPV Testing). Are you ready for a new era in Cervical Cancer Screening? College of American Pathologists HPV Meeting, September 21-22, 2002; Chicago, IL.

33. Josefsson AM, Magnusson PK, Ylitalo N, Sorensen P, Qwarforth-Tubbin P, Andersen PK, et al. Viral load of human papillomavirus 16 as a determinant for development of cervical carcinoma in situ: a nested case-control study. Lancet 2000; 355: 2189-93.

34. Yamazaki H, Sasagawa T, Basha W, Segawa T, Inoue M. Hybrid capture-II and LCR-E7 PCR assays for HPV typing in cervical cytologic samples. Int J Cancer 2001; 94: 222-7. 